\title{
ON THE WAY OF WEIGHT COEFFICIENT AND RESEARCH FOR THE HILBERT-TYPE INEQUALITIES
}

\author{
BICHENG YANG AND THEMISTOCLES M. RASSIAS
}

\begin{abstract}
The Hilbert-type inequalities are certain significant weight inequalities, which play an important role in mathematical analysis and its applications. In this paper, we introduce the way of weight coefficient and consider its applications to the Hilbert-type inequalities. We will summarize how to use the way of weight coefficient to obtain some new improvements and generalizations of the Hilbert-type inequalities.
\end{abstract}

Mathematics subject classification (2000): 26D15.

Key words and phrases: Hilbert's inequality, weight coefficient, Cauchy's inequality, $\beta$ function, Hölder's inequality.

\section{REFERENCES}

[1] G. H. Hardy, J. E. Littlewood and G. Polya, Inequalities, Cambridge Univ. Press, London, 1952.

[2] D. S. Mitrinovic, J. E. PeCARIC AND A. M. FinK, Inequalities Involving Functions and their Integrals and Derivatives, Kluwer Academic Publishers, Boston, 1991.

[3] D. S. Mitrinovic, Analytic inequalities, Springer-Verlag, New York, 1970.

[4] A. E. InGHAM, A note on Hilbert's inequality, J. London Math. Soc. 11 (1936), 237-240.

[5] L. C. Hsu AND Y. J. WANG, A refinement of Hilbert's double series theorem, J. Math. Res. Exp. 11:1 (1991), 143-144.

[6] Gao Mingzhe, A note on Hilbert double series theorem, Hunan Annals of Math., 12:1-2 (1992), $143-147$.

[7] Xu Lizhi and Guo YongKang, Not on Hardy-Riesz's extension of Hilbert's inequality, Chin. Quart. J. Math., 6:1 (1991), 75-77.

[8] Hu Ke, On Hilbert's inequality, Chin. Ann. of Math., 13B:1 (1992), 37-39.2.

[9] Hu Ke, On Hilbert inequality and its application, Advances in Math., 22:2 (1993), 160-163.

[10] Hu KE, Establishments and applications of the base inequalities, Jianxi College and University Press, Nanchang, 1998.

[11] Gao Mingzhe and TAn Li, Some improvements on Hilbert's integral inequality, J. Math. Anal. Appl., 229 (1999), 682-689. 237-240.

[12] Gao MingZhe, On the Hilbert inequality, J. for Anal. Appl., 18:4 (1999), 1117-1122.

[13] B. G. PaChPATtE, On some new inequalities similar to Hilbert's inequality, J. Math. Anal. Appl., 226 (1998), 166-179.

[14] Zhao Changuan, Generalization on two new Hilbert type inequalities, J. Math., 20:4 (2000), $413-416$.

[15] Zhao ChangJian And L. Debnath, Some new type Hilbert integral inequalities, J. Math. Anal. Appl., 262 (2001), 411-418.

[16] YANG BICHENG, On a new inequality similar to Hardy-Hilbert's inequality, Math. Ineq. Appl., 6:1 (2003), 37-44.

[17] YANG BICHENG, On a new Hardy-Hilbert's type inequality and applications, Acta Mathematica Sinica, 46:5 (2003) (to appear).

[18] Hong Yong, All-sided generalization about Hardy-Hilbert integral inequalities, Acta Mathematica Sinica, 44:4 (2001), 619-626.

[19] XU LiZHi AND WANG XINGHUA, The way of mathematical analysis and some examples, High Education Press, Beijing, 1985.

[20] YANG BICHENG, A refinement of Hilbert's inequality, Huanghuai J., 13:2 (1997), 47-51. (1993), 160-163. 
[21] Yang Bicheng and L. Debnath, Some inequalities involving $\pi$ and an application to Hilbert's inequality, Appl. Math. Lett., 12 (1999), 101-105.11.

[22] YANG Bicheng AND L. DeBnath, On a refinement of Hilbert's inequality, Classroom Notes, 2000, 773-779.

[23] YANG BICHENG, A strengthened Hilbert's inequality and its application, Journal of Xinyang Teachers College, 14:1 (2001), 40-43.

[24] YANG BichENG, On Hilbert's integral inequality, J. Math. Anal. Appl., 220 (1998), 778-785.

[25] YANG BICHENG, A note on Hilbert's integral inequalities, Chin. Quart. J. Math., 13:4 (1998), 83-86.

[26] YANG Bicheng, On generalization of Hilbert's theorem, J. Nanjing Univ. Math. Biquarterly, 17:1 (2000), 152-156.

[27] YANG BICHENG AND L. DEBNATH, On a generalization of Hilbert's integral inequality and its applications, Research Report Collection, 2:5 (1999), 731-741.

[28] YANG BICHENG, On a generalization of Hilbert's double series theorem, Math. Ineq. Appl., 5:2 (2002), 197-204.

[29] Kunng Jichang, Applied Inequalities, Hunan Education Press, Changsha, 1993.

[30] Xie Honggzheng, Lu ZhongXue And Xin YumeI, New Majorized results on Hilbert's integral inequality, Chin. Quart. J. Math., 16:4 (2001), 67-75.

[31] YANG BICHENG, On a generalization of Hilbert double series theorem, J. Nanjing Univ. Math. Biquarterly, 18:1 (2001), 145-152.

[32] G. H. HARDY, Note on a theorem of Hilbert concerning series of positive terms, Proc. London Math. Soc., 23:2 (1925), Records of Proc. xlv-xlvi.

[33] S. G. MikHLIN, Constants in some inequalities of analysis, John Wiley and Sons, New York, 1986.

[34] YANG Bicheng AND GaO MingZHe, On a best value of Hardy-Hilbert's inequality, Advances in Math., 26:2 (1997), 159-164.

[35] Gao Mingzhe and Yang Bicheng, On the extended Hilbert's inequality, Proc. Amer. Math. Soc., 126:3 (1998), 751-759.

[36] YANG BICHENG AND L. DEBNATH, On new strengthened Hardy-Hilbert's inequality, Internat. J. Math. Math. Sci., 21:2 (1998), 403-408.

[37] YANG BICHENG, On a strengthened version of the more accurate Hardy-Hilbert's inequality, Acta Mathematica Sinica, 42:6 (1999), 1103-1110.

[38] YANG Bicheng, On a strengthened Hardy-Hilbert's inequality, J. Ineq. in Pure and Applied Math., 1:2 (2000), Article 22.

[39] YANG BICHENG, On a refinement of Hardy-Hilbert's inequality and its applications, North. Math. J., 16:3 (2000), 279-286.

[40] YANG BICHENG, On generalizations of Hardy-Hilbert's integral inequalities, Acta Mathematica Sinica, 41:4 (1998), 839-844.

[41] YANG BICHENG, On Hardy-Hilbert's integral inequality and its equivalent form, North. Math. J., 19:2 (2003), 139-148.

[42] YANG BICHENG, On a general Hardy-Hilbert's integral inequality with a best value, Chinese Annals of Math., 21A:4 (2000), 401-408.

[43] YANG BichenG, On Hardy-Hilbert's integral inequality, J. Math. Anal. Appl., 261 (2001), 295-306.

[44] Wang ZhuXI AND Guo DunRIN, An introduction to special functions, Science Press, Beijing, 1979.

[45] YANG BICHENG, On generalizations of Hardy-Hilbert's inequality and its equivalent form, Journal of Mathematics, 23:4 (2003) (to appear).

[46] KuAng Jichang, On new extensions of Hilbert's integral inequality, J. Math. Anal. Appl., 235 (1999), 608-614.

[47] Hu Ke, On Hardy-Littlewood-Polya inequality, Acta Mathematica Tcientia, 20 (2000), 684-687.

[48] YANG BICHENG, On an extension of Hardy-Hilbert's inequality, Chinese Annals of Math., 23A:2 (2002), 247-254.

[49] YANG Bicheng AND L. Debnath, On a new generalization of Hardy-Hilbert's inequality and its applications, J. Math. Anal. Appl., 233 (1999), 484-497.

[50] YANG BICHENG, On a new extension of Hardy-Hilbert's inequality and its applications, International Journal of Pure and Applied Mathematics, 5:1 (2003), 57-66.

[51] YANG Bicheng, On a Multiple Hardy-Hilbert's inequality, Chin. Annals. of Math., 24A:6 (2003) (to appear).

[52] He LePing, Yu Jiangming AND GaO MingzHe, An extension of Hilbert's integral inequality, Journal of Shaoguan Univ. (Natural Science), 23:3 (2002), 25-30. 